\title{
Effects of Soil and Foliar Applied Fertilizers on Growth, Yield and Sugar Quality of Two Sugarcane Cultivars under Rainfed Conditions
}

\begin{abstract}
Background: In north-eastern Thailand, sugarcane is planted normally in late rainy season wherein the plants may experience drought stress during its early growth stage in dry season and waterlogging stress during late growth stage at peak of rainy season. Hence, the objective of the present study was to investigate the effects of soil application alone and soil combined with foliar application of nutrients on growth, yield and sugar quality of sugarcane grown under rainfed conditions.

Methods: The field experiment was conducted during November 2016 to December 2017. A split-plot design with three replications was laid out. The two sugarcane cultivars (KK3, K93-219) were assigned as main plots. The fertilizer application methods were assigned as sub-plots that comprised of four treatments: (1) soil applied NPK, (2) soil NPK + foliar N and K applied at 90 days after planting (DAP), (3) soil NPK + foliar N and K applied at 210 DAP and (4) soil NPK + foliar N and K applied at 90 and 210 DAP.

Result: The soil NPK + foliar N and K applied at 90 and 210 DAP improved yield components and cane yield. The cultivar K93-219 produced significantly higher cane yield than KK3. The fertilizer application methods and cultivars had no significant effect on sugar quality such as brix (\%), purity (\%), polarity (\%), fiber (\%) and commercial cane sugar (CCS-\%).

Key words: Drought, Flood, Foliar N and K, Soil NPK, Sugarcane.
\end{abstract}

\section{INTRODUCTION}

Sugarcane (Saccharum officinarum L.) is grown in over 1.91 million hectares in Thailand with an average productivity of $44.31 \mathrm{t} \mathrm{ha}^{-1}$. Out of total area, $43.7 \%$ is cultivated in the northeast Thailand (Office of the Cane and Sugar Board, 2020 ) of which approximately $90 \%$ is under rainfed conditions. Most agricultural land in the region are toposequence; a sequence of sloped land separated into a series of upland fields and lowland fields. At different position lowland fields along the toposequence and the upper fields are commonly planted to early maturing rice (Oryza sativa L.) varieties while the lower fields are grown with late maturing rice varieties. In general, the upper paddy fields produced low yield since most underground water level occur below the soil surface during growing season (Hayashi et al., 2007; Boling et al., 2008). Recently, farmers began managing these paddies by growing sugarcane instead of rice crop. However, sugarcane planted in late rainy season may expose to drought during the period of dry season (January-March) and subsequently to temporary flooding (August-September) during the peak of rainy season in the region. As mentioned earlier, sugarcane faces drought in the formative phase and flood in the grand growth phase which may reduce yield. Nutrient uptake by plants generally decreases under drought conditions owing to a substantial decrease in transpiration rates and impaired active transport and membrane permeability. A decline in soil moisture content is associated with a decrease in the diffusion rate of nutrients from the soil matrix to the absorbing root surface (Steffens et al., 2005). The application of potassium (K) has
${ }^{1}$ Department of Agronomy, Khon Kaen University, Khon Kaen, Thailand.

${ }^{2}$ School of Plant, Environmental and Soil Sciences, Louisiana State University, USA.

${ }^{3}$ Department of Soil Science and Environment, Khon Kaen University, Thailand.

${ }^{4}$ Department of Agricultural Extension and Agricultural Systems, Khon Kaen University, Thailand.

Corresponding Author: A. Polthanee, Department of Agronomy, Khon Kaen University, Khon Kaen, Thailand. Email: panan@kku.ac.th

How to cite this article: Bamrungrai, J., Polthanee, A., Tubana, B., Tre-loges, V. and Promkhambut, A. (2022). Effects of Soil and Foliar Applied Fertilizers on Growth, Yield and Sugar Quality of Two Sugarcane Cultivars under Rainfed Conditions. Indian Journal of Agricultural Research. DOI: 10.18805/IJARe.AF-688.

Submitted: 01-09-2021 Accepted: 02-12-2021 Online: 16-01-2022

been found to increase sugarcane growth during drought consequently increasing cane yield (Manickam et al., 2009). Under limited water supply, more $\mathrm{K}$ is required for the balance of photosynthetic $\mathrm{CO}_{2}$ assimilation rates, defense of chloroplasts from oxidative damage, important of related disruption in carbohydrate metabolism, regulation of stomatal and relations of water status (Cakmak, 2005). Foliar application is the method to support plant nutrient uptake through leaves. Foliar application of potassium salt of active phosphorus increased the photosynthetic activities by protecting the photosynthetic machinery during unfavorable conditions (Verma et al., 2021). In flooded soil, nutrient 
uptake decreased due to reduce root activity cause by oxygen deficiency (Drew, 1992). Sugarcane flooded (three months) reduced by 10 to $78 \%$ of $\mathrm{N}, \mathrm{P}$ and $\mathrm{K}$ concentration in leaf which indicated that the decrease in sugarcane growth during flooding might be due to reduced uptake of both macro and micro-nutrients (Gillbert et al., 2007). The application of urea $(0.3 \%)$, potassium nitrate $\left(\mathrm{KNO}_{3}, 0.5 \%\right)$ and calcium nitrate $\left(\mathrm{CaNO}_{3}, 0.4 \%\right)$ increased leaf area and shoot weight of sugarcane grown under flooding conditions (Jain et al., 2016). In previous work, its focus normally on fertilizer application through the soil. There is little information on soil combined foliar fertilizer application and dual effect of drought and flood stress in different sugarcane cultivars. Hence, the present study was conducted to determine the effects of soil NPK and soil NPK combined foliar $\mathrm{N}$ and $\mathrm{K}$ fertilizer applied during drought and flood period on growth, yield and sugar quality of two sugarcane cultivars grown under rainfed conditions.

\section{MATERIALS AND METHODS}

\section{Experimental site}

The field experiment was conducted on farmer's field at $\mathrm{Na}$ Fai-Nue village, Nampong district with latitude of $16^{\circ} 43^{\prime} \mathrm{N}$ and longitude of $102^{\circ} 59^{\prime} \mathrm{E}$, Khon Kaen province of Thailand from November 2016 to December 2017. The field was converted from a paddy field where rice was cultivated for one year. The soil is loamy sand in texture; sand $73.6 \%$, silt $15.6 \%$ and clay $10.7 \%$. The soil is slightly acidic with a pH of 5.23 , electric conductivity (EC) $0.025 \mathrm{dS} / \mathrm{m}$ and low organic matter content $(0.5 \%)$. The total $\mathrm{N}$, available $\mathrm{P}$ and exchangeable $\mathrm{K}$ measured from the soil were $138.51,7.42 \mathrm{~kg}$ and $254.4 \mathrm{mg} / \mathrm{kg}$, respectively. The total amount of rainfall during the growth period was 890 $\mathrm{mm}$ with rainfall peak in July. However, rainfall exhibited distribution for the entire growth period with an additional summer rain in March and April at tillering stage and late rain in October at ripening phase.

\section{Experimental design and treatments}

The experiment was laid out in a split-plot design with three replications. The two sugarcane cultivars (KK3 and K93-219) were assigned as main-plot. The four methods of fertilizer application were assigned as sub-plots (Table 1). Soil was tilled two times and the furrows were built from topsoil by tractor with $1.5 \mathrm{~m}$ spacing between rows. Sugarcane stalks at 11 months of age were used for planting material with the middle section of the stalks mostly used as material. Single node stalk segments of each cultivar were planted on December 19, 2016, in 5 rows $\times 4$ meters long plots with 0.50 -meter plant spacing. The crop used residual soil moisture at early growth stage with initial soil moisture at $17 \%$ (by weight). Soil-applied fertilizers using fertilizer grade 16-16-8 $\left(\mathrm{N}, \mathrm{P}_{2} \mathrm{O}_{5}, \mathrm{~K}_{2} \mathrm{O}\right)$ at rate of (100-100-50) kg ha-1 in all treatments were applied in split, first at planting (50\%) and then $120 \mathrm{DAP}(50 \%)$ in all treatments. For foliar application, urea $5 \%\left(12.4 \mathrm{~kg} \mathrm{ha}^{-1}\right)$ (Sangplung, 1978) and $\mathrm{K}_{2} \mathrm{O} 0.5 \%$ (1.24 kg ha-1) (Jain et al., 2016) were diluted in one liter water and sprayed to the crop about $30-40 \mathrm{~cm}$ from the leaf canopy using backpack sprayer. The foliar fertilizer application was done at 90 DAP during rainless period (30 March) and at 210 DAP during flooding period (28 July). The plots were kept weed-free by manual weeding twice at 60 and 90 DAP. No insects and disease were detected thus no control was implemented in the present experiment.

\section{Water level below and above ground surface}

Observation wells of perforated polyvinyl chloride (PVC) tubes were installed at $150 \mathrm{~cm}$ depth in the middle of experimental field. Ground water level below soil surface and standing water above soil surface were recorded at twoweeks interval for entire the growth period according to Polthanee (1989). In the present experiment mean ground water level initiated about $100 \mathrm{~cm}$ below soil surface at time of planting (December) (Fig 1). Then, ground water level came up above soil surface at the peak (June to mid-August) of rainy season for $85 \mathrm{~d}$ (Fig 1).

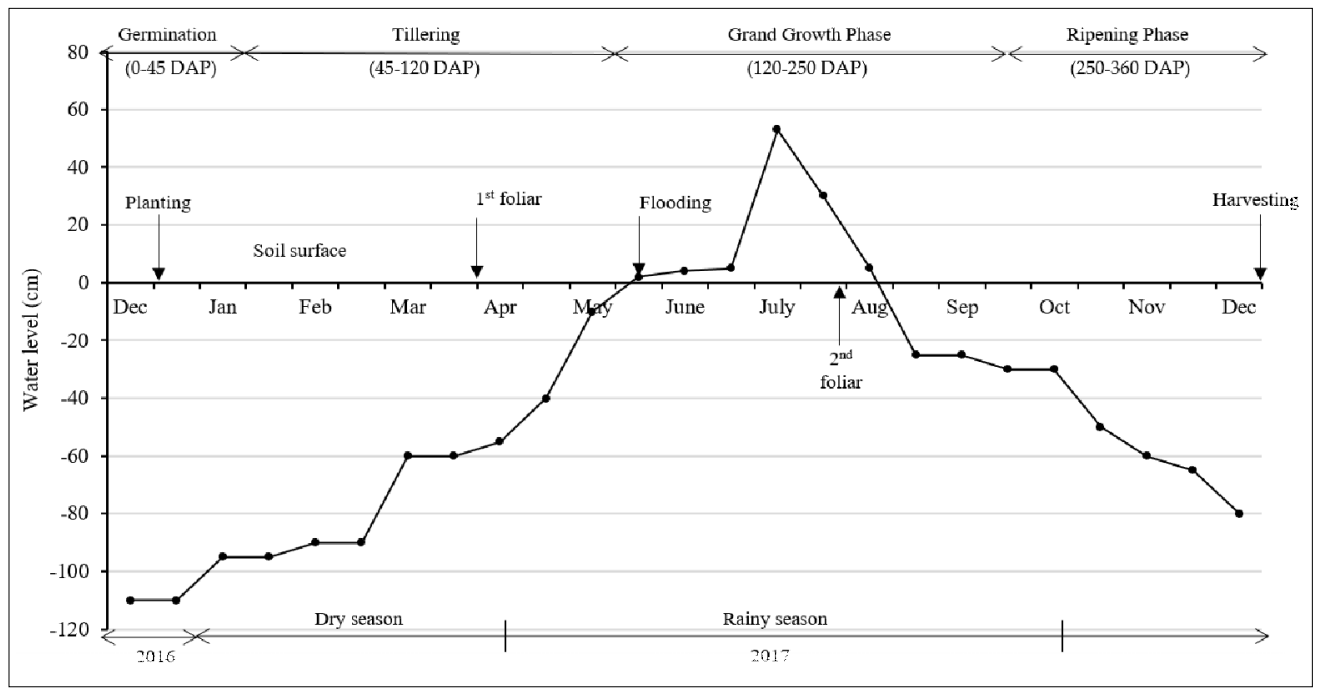

Fig 1: Water level below soil surface (-values) and above soil surface (+values) at experimental site during the growth period; DAP $=$ Days after planting. 


\section{Plant growth}

The plant height was measured at harvest by measured from base (soil surface) to the leaf tip of main stalk using a meter rod. For leaf area, the leaves were selected randomly from 10 main stems at 90 and 210 DAP of each plots. Thereafter, the leaf samples were measured with a leaf area meter (ACC-400, Hayashi Denken, Japan).

\section{Yield components and cane yield}

The number of millable cane was counted from four plants randomly selected from each plot at harvest. Thereafter, the samples were determined as fresh weight plant. The single millable cane fresh weight was calculated with fresh weight plant $^{-1}$ divided by the number plant. For cane yield, the millable cane fresh weight was recorded from the areas of $3.50 \mathrm{~m} \times 6.50 \mathrm{~m}$ located in the middle rows of the plots and expressed as cane yield $\left(\mathrm{t} \mathrm{ha}^{-1}\right)$.

\section{Nutrient concentration and sugar qualitative parameters}

The top visible dewlap (TVD) of three plants were randomly selected from each plot at 300 DAP. The plant samples were dried at $80^{\circ} \mathrm{C}$ for $48 \mathrm{~h}$ until constant dry weight and analyzed for total $\mathrm{N}(\%)$ and total $\mathrm{K}(\%)$. The qualitative parameters such as brix (\%), purity (\%), polarity (\%), fiber (\%) and commercial cane sugar (CCS-\%) were evaluated at harvest from the stalk samples.

\section{Statistical analysis}

The data was analyzed using the computer software Statistix 10 (Statistix 10, Analytical Software, USA). Analysis of variance (ANOVA) with the main factor fertilization treatment and cultivar (factor fertilization treatment nested in factor cultivar) was performed for the parameters yield and other variables. For parameters with significant fertilizer treatment effect $(p \leq 0.05)$, comparison of treatment means was performed using the least significant difference test (LSD) at $p \leq 0.05$ level of confidence.

\section{RESULTS AND DISCUSSION}

\section{Nutrient concentration in top visible dewlap leaf (TVD)}

Fertilizer application methods and cultivars had no significant effect on $\mathrm{N}$ and $\mathrm{K}$ concentration in TVD leaf but there was significantly effect on $\mathrm{K}$ (Table 2). Foliar $\mathrm{N}$ and $\mathrm{K}$ application gave higher $\mathrm{N}$ and $\mathrm{K}$ concentration than that of no-foliar application in all treatments (Table 2). As mentioned above, the plants experienced prolong flooding stress. For this reason, sugarcane plants formed adventitious roots on their submerged stems during the flooding events. The adventitious roots formation is considered an important adaptation of sugarcane to flooding stress (Gomathi et al., 2010a; Jaiphong et al., 2016). Under flooding condition, soil rapidly become anoxic, causing nutrient availability in the

Table 1: Treatments in sub-plots of application fertilizer methods.

\begin{tabular}{|c|c|c|c|c|c|}
\hline \multirow{2}{*}{ Treatments } & \multicolumn{3}{|c|}{ Soil applied $\left(\mathrm{kg} \mathrm{ha}^{-1}\right)$} & \multicolumn{2}{|c|}{ Foliar applied $\left(\mathrm{kg} \mathrm{ha}^{-1}\right)$} \\
\hline & $\mathrm{N}$ & $\mathrm{P}_{2} \mathrm{O}_{5}$ & $\mathrm{~K}_{2} \mathrm{O}$ & $\mathrm{N}$ & $\mathrm{K}_{2} \mathrm{O}$ \\
\hline Soil NPK & 56 & 28 & 56 & none & none \\
\hline Soil NPK+Foliar at $90 \mathrm{DAP}$ & 56 & 28 & 56 & 12.4 & 1.24 \\
\hline Soil NPK+Foliar at 210 DAP & 56 & 28 & 56 & 12.4 & 1.24 \\
\hline Soil NPK+Foliar at 90 and 210 DAP & 56 & 28 & 56 & 24.8 & 2.48 \\
\hline
\end{tabular}

Note: Foliar applied $\mathrm{N}$ (urea $5 \%$ ) diluted in one liter water, $\mathrm{K}\left(\mathrm{K}_{2} \mathrm{O} 0.5 \%\right)$ diluted in one liter water, soil applied by split at planting (50\%) and 120 DAP $(50 \%)$, DAP = Days after planting.

Table 2: Yield components, cane yield and growth parameters of sugarcane as affected by methods of fertilizer application and cultivars under rainfed conditions.

\begin{tabular}{|c|c|c|c|c|c|c|}
\hline \multirow{2}{*}{ Treatment } & \multirow{2}{*}{$\begin{array}{c}\text { Millable cane } \\
\text { number (no./plant) }\end{array}$} & \multirow{2}{*}{$\begin{array}{l}\text { Single millable } \\
\text { cane weight }(\mathrm{kg})\end{array}$} & \multirow{2}{*}{$\begin{array}{l}\text { Cane yield } \\
\qquad(\mathrm{t} \mathrm{ha-1})\end{array}$} & \multicolumn{2}{|c|}{ Leaf area $\left(\mathrm{cm}^{2} /\right.$ tiller $)$} & \multirow{2}{*}{$\begin{array}{l}\text { Plant height } \\
\qquad(\mathrm{cm})\end{array}$} \\
\hline & & & & $90 \mathrm{DAP}$ & $210 \mathrm{DAP}$ & \\
\hline \multicolumn{7}{|l|}{ Method of application (M) } \\
\hline Soil NPK & $3.6 \mathrm{c}$ & $1.4 \mathrm{~b}$ & $66.2 \mathrm{c}$ & 884.4 & 1372.6 & 245.8 \\
\hline Soil NPK+Foliar at 90 DAP & $4.1 \mathrm{ab}$ & $1.3 b$ & 87. $5 b$ & 897.1 & 1305.6 & 245.9 \\
\hline Soil NPK+Foliar at $210 \mathrm{DAP}$ & $4.6 \mathrm{~b}$ & $1.6 \mathrm{ab}$ & $76.8 \mathrm{bc}$ & 757.7 & 1238.7 & 252.1 \\
\hline Soil NPK+Foliar at 90 and 210 DAP & $4.7 a$ & $1.8 \mathrm{a}$ & $111.8 \mathrm{a}$ & 877.7 & 1471.2 & 245.3 \\
\hline F-test & * & * & ** & ns & ns & ns \\
\hline \multicolumn{7}{|l|}{ Cultivar (C) } \\
\hline KK3 & 4.4 & $1.3 b$ & $78.1 \mathrm{~b}$ & $698.4 b$ & $1104.2 b$ & $251.1 a$ \\
\hline K93-219 & 5.2 & $1.7 a$ & $117.5 a$ & $855.3 a$ & 1347.1a & $243.5 b$ \\
\hline F-test & ns & * & ** & ** & ** & * \\
\hline Interaction $\mathrm{M} \times \mathrm{C}$ & ns & ns & ns & ns & ns & ns \\
\hline
\end{tabular}

Notes: $\mathrm{ns},{ }^{*},{ }^{* *}=$ non-significant and significant at $p \leq 0.01$ probability levels, respectively. Mean with the difference small letters in each column is significantly different by least significant difference $(p \leq 0.05)$; DAP $=$ Days after planting. 
soil to decrease (Kozlowski and Pallardy, 1984). Flooding induced severe deficiencies of $\mathrm{N}, \mathrm{P}$ and $\mathrm{K}$ in sugarcane; the $\mathrm{N}$ and $\mathrm{K}$ concentration were below critical deficiency level (Singh et al., 2019). Furthermore, the lack of oxygen may cause decay of the primary root systems (Visser et al., 2015). By lower nutrient availability together with impeded functioning of the primary roots may lead to nutrient deficiency in the plant (Trought and Drew, 1980). Previous studies reported that the adventitious roots can take up nutrients and water from flood water (Trought and Drew, 1980; Khan et al., 1982; Zhang et al., 2017). However, flooding in sugarcane (three months) resulted in reduction by 10 to $78 \%$ in N, P and K concentration in leaf (Gilbert et al., 2007). The application of farm yard manure and foliar spray of $\mathrm{KCl}$ and urea proved effective in increasing $\mathrm{K}$ ions concentration which regulates the opening and closing of stomata hence transpiration rate (Chand et al., 2010). Under drought conditions, the application of nitrogen $(\mathrm{N})$ in solid and foliar forms on two broad leave and narrow leave cane varieties proved to be advantageous (Ali et al., 1997). Foliar $\mathrm{N}$ and $\mathrm{K}$ under waterlogged conditions can improved nutrients uptake through leaves. Foliar absorption occurs through a process that initially requires penetration into the cuticle (passive percolation or surface adsorption) and then passes (active absorption) through the cells (Fernandez and Brown, 2013). For cultivars, KK3 was significantly $(p \leq 0.05)$ higher $\mathrm{K}^{+}$concentration in TVD leaf than K93-219 (Table 2). Waterlogging induced $28 \%$ and $30 \%$ reduction in leaf and stem $\mathrm{N}$ content, respectively and the reduction was comparatively lesser in resistant clones (Gomathi et al., 2010a; Gomathi and Chandran, 2012).

\section{Growth character performances}

Plant height at harvest and leaf area at 90 and 210 DAP had no significant affected by fertilizer application methods but there is significantly different between two cultivars in plant height and leaf area (Table 3). The highest plant height was observed in KK3. While, K93-219 gave the highest leaf area at 90 and 210 DAP. Foliar N application under waterlogged condition increased leaf area and shoot weight was reported by Jain et al. (2016).

\section{Yield components and cane yield}

Fertilizer application methods was significantly different $(p \leq 0.05)$ in millable cane number (Table 3$)$. The maximum millable cane numbers were attained in the soil NPK + foliar $\mathrm{N}$ and $\mathrm{K}$ application at 90 and $210 \mathrm{DAP}$. Similar result was observed in single millable cane weight (Table 3 ). This was associated with higher $\mathrm{K}$ concentration in TVD of such treatment than those of the other treatments in the present study (Table 2). This means that high $\mathrm{K}$ content in plants play an important role in contribution the single millable cane weight. A sustained supply of $\mathrm{K}^{+}$throughout the growing season will facilitate greater shifting of dry matter from leaf to stem, enhancing the translocation of more assimilates from source to sink (Mengel and Haeder, 1977). It is an enzyme activator in photosynthesis, protein synthesis, starch formation and translocation of proteins and sugars (Filho, 1985; Kwong, 2002; Wood and Schroeder, 2004). Furthermore, additional foliar $\mathrm{N}$ and $\mathrm{K}$ at 90 and $210 \mathrm{DAP}$ providing $\mathrm{N}$ and $\mathrm{K}$ for sugarcane at tillering and grand growth phase supports better plant growth and development reach to ripening phase (millable cane) than the other treatments. Foliar $\mathrm{K}$ application at tillering phase (90 DAP) resulted in increased millable cane count was reported by Mathew et al. (2004). The increase in blackgram and cowpea grain weight due to the application of foliar spray were also reported by Geetha and Velayutham (2016); Anitha et al. (2005).

For cultivars, millable cane number and single millable cane weight were significant different in single millable cane weight (Table 3 ). The cultivars K93-219 produced higher single millable cane weight than KK3 cultivar. This was associated with K93-219 cultivar gave higher leaf area than KK3 cultivar (Table 3 ). The cultivar K93-219 identified as waterlogging tolerance cultivar (Office of the Cane and Sugar Board Thailand, 2016; Palachai et al., 2019). Therefore, the K93-219 could provide more of food from photosynthesis and translocate to stalk than that of KK3 cultivar.

Regarding cane yield, fertilizer application methods and cultivars were significantly different in cane yield (Table 3 ). The maximum cane yield was obtained in soil NPK combined foliar $\mathrm{N}$ and $\mathrm{K}$ application at 90 and $210 \mathrm{DAP}$. This was probably due to higher single millable cane weight and millable cane number than those of other treatments. The cultivar K93-219 produced significantly higher cane yield than KK3. This was due to the K93-219 gave higher single millable cane weight and millable cane number than KK3 cultivar.

Table 3: Total nitrogen and total potassium concentration of top visible dewlap (TVD) leaf of sugarcane as affected by methods of fertilizer application and cultivars under rainfed conditions.

\begin{tabular}{lcc}
\hline Treatment & Total N (\%) & Total K (\%) \\
\hline Method of application (M) & & \\
Soil NPK & 1.52 & $1.45 \mathrm{~b}$ \\
Soil NPK+Foliar at 90 DAP & 1.72 & $2.05 \mathrm{a}$ \\
Soil NPK+Foliar at 210 DAP & 1.68 & $1.76 \mathrm{ab}$ \\
Soil NPK+Foliar at 90 and 210 DAP & 1.78 & $2.10 \mathrm{a}$ \\
F-test & $\mathrm{ns}$ & $*$ \\
Cultivar (C) & & \\
KK3 & 1.68 & $2.00 \mathrm{a}$ \\
K93-219 & 1.53 & $1.68 \mathrm{~b}$ \\
F-test & $\mathrm{ns}$ & $*$ \\
Interaction $\mathrm{M} \times \mathrm{C}$ & $\mathrm{ns}$ & $\mathrm{ns}$ \\
\hline
\end{tabular}

Notes: $n s,{ }^{*}=$ non-significant and significant at $(p \leq 0.05)$ probability levels, respectively. Mean with the difference small letters in each column is significantly different by least significant difference $(p \leq 0.05) ;$ DAP $=$ Days after planting. 
Effects of Soil and Foliar Applied Fertilizers on Growth, Yield and Sugar Quality of Two Sugarcane Cultivars under Rainfed Conditions

Table 4: Sugar quality parameters of sugarcane as affected by methods of fertilizer application and cultivars under rainfed conditions.

\begin{tabular}{|c|c|c|c|c|c|}
\hline Treatment & Brix (\%) & Polarity (\%) & Purity (\%) & Fiber (\%) & $\operatorname{CCS}(\%)$ \\
\hline \multicolumn{6}{|l|}{ Method of application (M) } \\
\hline Soil NPK & 19.9 & 16.2 & 75.1 & 11.5 & 12.4 \\
\hline Soil NPK+Foliar at $90 \mathrm{DAP}$ & 19.3 & 15.8 & 73.1 & 11.2 & 11.9 \\
\hline Soil NPK+Foliar at 210 DAP & 18.9 & 15.4 & 71.8 & 11.0 & 11.8 \\
\hline Soil NPK+Foliar at 90 and 210 DAP & 21.4 & 17.2 & 80.6 & 12.2 & 13.4 \\
\hline F-test & ns & ns & ns & ns & ns \\
\hline \multicolumn{6}{|l|}{ Cultivar (C) } \\
\hline KK3 & 22.5 & 18.3 & 81.1 & 12.8 & 14.8 \\
\hline K93-219 & 20.6 & 16.8 & 81.6 & 12.1 & 12.5 \\
\hline F-test & ns & ns & ns & ns & ns \\
\hline Interaction $\mathrm{M} \times \mathrm{C}$ & ns & ns & ns & ns & ns \\
\hline
\end{tabular}

Notes: $\mathrm{ns}=$ non-significant. Mean with the difference small letters in each column is significantly different by least significant difference $(p \leq 0.05) ;$ DAP $=$ Days after planting.

\section{Sugar quality}

Fertilizer application methods and cultivars had no significant effect on sugar quality components including brix (\%), polarity (\%), purity (\%), fiber (\%) and CCS (\%) (Table 4). In general, sugarcane responded to $\mathrm{K}$ fertilizer by an increase in cane yield without any change in sucrose concentration in the cane (Kwong, 2002; Shukla et al., 2009). In contrast, nitrogen applied split into solid and foliar forms on two broad leaves and narrow leaves cane varieties increased polarity (\%) juice and CCS (\%) of sugarcane (Ali et al., 1997).

\section{CONCLUSION}

The soil NPK + foliar $\mathrm{N}$ and $\mathrm{K}$ application in dry season at 90 DAP and rainy season at 210 DAP during flooding stress had compounding positive effect on yield components and subsequently improving cane yield, but it had no significant effect on sugar quality components. The sugarcane cultivar K93-219 produced significantly higher cane yield than KK3.

\section{ACKNOWLEDGEMENT}

We would like to express our gratitude to the Thai Royal Golden Jubilee Program (Grant no. PHD/0071/2556) and Research Scholarships organized by Graduate School, Khon Kaen University, Thailand.

Conflict of interest: None.

\section{REFERENCES}

Ali, S.A., Afridi, M.M.R.K., Singh, R.G. (1997). Comparative efficiency of soil and foliar applied nitrogen in sugarcane, quality parameters and leaf nitrogen content. Indian Journal of Plant Physiology. 2(1): 75-78.

Anitha, S., Sreenivan, E., Purushothaman, S.M. (2005). Response of cowpea [Vigna unguiculata (L.) Walp] to foliar nutrition of zinc and iron in the oxisols of Kerala. Legume Research. 28(4): 294-296.
Boling, A.A., Tuong, T.P., Suganda, H., Konboon, Y., Harupihitvitaya, D., Bouman, B.A.M., France, D.T. (2008). The effect of toposequence position on soil properties, hydrology and yield of rainfed lowland rice in Southeast Asia. Field Crops Research. 106: 22-33.

Cakmak, I. (2005). The role of potassium in alleviating detrimental effects of abiotic stresses in plants. Journal of Plant Nutrition and Soil Science. 168: 521-530.

Chand, M., Lal, R., Khippal, A., Singh, R., Narang, A.K. (2010). Drought management in sugarcane during pre-monsoon period. Sugar Tech. 12(1): 64-66.

Drew, M.C. (1992). Soil aeration and plant root metabolism. Soil Science. 154: 259-268.

Fernandez, V. and Brown, P.H. (2013). From plant surface to plant metabolism: The uncertain fate of foliar-applied nutrients. Frontiers in Plant Science. 4: 289.

Filho, J.O. (1985). Potassium Nutrition of Sugarcane. In: Potassium in Agriculture. (Munson, R.D. Edn.). American Society of Agronomy, Crop Science Society of America, Soil Science Society of America, Madison. pp 1045-1062.

Geetha, P. and Velayutham, A. (2016). Yield attributes, yield and uptake of nutrients as influenced by basal and foliar application of nutrients on rice fallow blackgram. Indian Journal of Agricultural Research. 50(2): 122-125.

Gilbert, R.A., Rainbolt, C.R., Morris, D.R., Bennett, A.C. (2007). Morphological responses of sugarcane to long-term flooding. Agronomy Journal. 99: 1622-1628.

Gomathi, R., Chandran, K., Gururaja Rao, P.N., Rakkiyappan, P. (2010a). Effect of flooding in sugarcane and its management. Published by The Director, Sugarcane Breeding Institute (SBI-ICAR); Coimbatore, Extension Pub, No. 185.

Gomathi, R. and Chandran, K. (2012). Physiological Markers for Screening Waterlogging Resistance in Sugarcane. Proceedings of International Symposium on New Paradigms in Sugarcane Research. Coimbatore: SSRD and SBI.

Hayashi, S., Kamoshita, A., Yamagishi, J., Kotchasatit, A., Jongdee, B. (2007). Genotypic differences in grain yield of transplanted and direct-seeded rainfed lowland rice (Oryza sativa L.) in northeastern Thailand. Field Crops Research. 102: 9-2. 
Jain, R., Singh, S.P., Singh, A., Singh, S., Chandra, A. (2016). Response of foliar application of nitrogen compounds on sugarcane grown under waterlogging stress. Sugar Tech. 18: 433-436.

Jaiphong T., Tominaga, J., Watanabe, K., Nakabaru, M., Takaragawa, H., Suwa, R., Ueno, M., Kawamitsu, Y. (2016). Effects of duration and combination of drought and flood conditions on leaf photosynthesis, growth and sugar content in sugarcane. Plant Production Science. 19: 427-437.

Khan, M.R., Ventura, W., Vergara, B.S. (1982). Uptake through aquatic roots and distribution of $15 \mathrm{~N}$-tagged ammonium in deepwater rice. Proceedings of the 1981 International Deepwater Rice Workshop. Los Baños, Philippines. pp. 321.

Kozlowski, T.T. and Pallardy, S.G. (1984). Flooding and Plant Growth ( $1^{\text {st }}$ Edn.). Academic Press, Florida. pp. 356.

Kwong, K.F. (2002). The Effects of Potassium on Growth, Development, Yield and Quality of Sugarcane. Proceedings International Symposium on the Role of Potassium in Nutrient Management for Sustainable Crop Production in India. pp. 430.

Manickam, G., Jayachandran, M., Balasubramanian, R., Pameerselvam, R., Rajenderan, B. (2009). Effect of integrated drought management practices on yield and quality of sugarcane. Cooperative Sugar. 41(10): 41-43.

Matthew, T., Kurian, T.M., George, B., Chorian, S., Kuriakose, J.M., Sreekumar, K., Jayakumar, G. (2004). Effect of time and mode of application of potassium on the growth, yield and quality of sugarcane ratoon. Sugar Tech. 6(1-2): 81-83.

Mengel, K. and Haeder, H.E. (1977). Effect of potassium supply on the rates of phloem sap exudation and the composition of phloem sap of Ricinis communis. Plant Physiology. 59: 282-284.

Office of the Cane and Sugar Board (Thailand). (2016). Sugarcane cultivars in Thailand. Khon Kaen prints Ltd. Khon Kean, Thailand.

Office of the Cane and Sugar Board (Thailand). (2020). Sugarcane cultivars in Thailand. Khon Kaen prints Ltd. Khon Kean, Thailand.

Palachai, C., Songsri, P., Jongrungklang, N. (2019). Comparison of yield components of sugarcane varieties grown under natural short- and long-term water-logged conditions in Thailand. SABRAO Journal of Breeding and Genetics. 51(1): 80-92.

Polthanee, A. (1989). Field-level drainage requirement of pre-rice mung bean crop in a waterlogged-prone environment. Doctor of Philosophy. Faculty of the Graduate School, University of the Philippines. $351 \mathrm{p}$.
Sangplung, N. (1978). Response of sugarcane to foliar application of urea fertilizer. Doctor of Physiology. Faculty of the Graduate school. University of the Philippines. $75 \mathrm{p}$.

Shukla, S.K., Yadav, R.L., Singh, P.N., Singh, I. (2009). Potassium nutrition for improving stubble bud sprouting, dry matter partitioning, nutrient uptake and winter-initiated sugarcane (Saccharum spp. hybrid complex) ratoon yield. European Journal of Agronomy. 30(1): 27-33.

Singh, S., Singh, S.P., Pathak, A.D., Pandey, N. (2019). Assessment of waterlogging induced physiobiochemical changes in sugarcane varieties and its association with waterlogging tolerance. Journal of Environmental Biology. 40(3): 384392.

Steffens, D., Hutsch, B.W., Eschholz, T., Losak, T., Schubert, S. (2005). Waterlogging may inhibit plant growth primarily by nutrient deficiency rather than nutrient toxicity. Plant, Soil and Environment. 51(12): 545-552.

Trought, M.C.I.T. and Drew, M.C. (1980). The development of waterlogging damage in wheat seedling (Triticum aestivum L.). 2. Accumulation and redistribution of nutrients by the shoot. Plant and Soil. 56(2): 187-199.

Verma, K.K., Song, X.P., Verma, C.L., Mukesh, K.M., Guo, D.J., Rajput, V.D., Sharma, A., Wei K.J., Chen, G.L., Solomon, S., Li, Y.R. (2021). Predication of photosynthetic leaf gas exchange of sugarcane (Saccharum spp.) leaves in response to leaf positions to foliar spray of potassium salt of active phosphorus under limited water irrigation. ACS OMEGA. 6(3): 2396-2409.

Visser, E.J.W., Zhang, Q., De Gruyter, F., Martens, S., Huber, H. (2015). Shade affects responses to drought and floodingacclimation to multiple stresses in bittersweet (Solanum dulcamara L.). Plant Biology. 18: 112-119.

Wood, A.W. and Schroeder B.L. (2004). Potassium: A critical role in sugarcane production, particularly in drought conditions. Proceedings of the Australian Society of Sugarcane Technologists, Queensland. pp. 1-11.

Zhang, Q., Huber, H., Beljaars, S.J.M., Birnbaum, D., de Best, S., de Kroon, H., Visser, E.J.W. (2017). Benefits of floodinginduced aquatic adventitious roots depend on the duration of submergence: Linking plant performance to root functioning. Annals of Botany. 120: 171-180. 